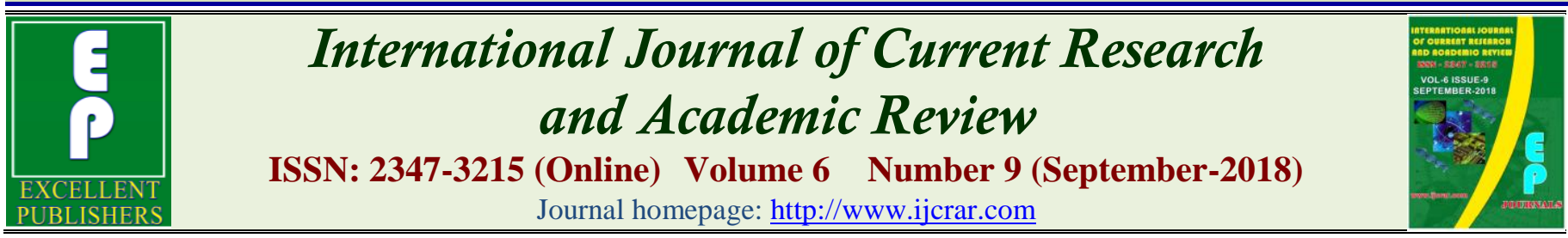

doi: https://doi.org/10.20546/ijcrar.2018.609.010

\title{
Sustainable Indigenous Knowledge Systems in Agriculture for Climate Change Adaptation and Mitigation in Southeast Nigeria
}

\author{
J. U. Chikaire ${ }^{1 *}$, N. E. Okereke - Ejiogu ${ }^{1}$ and E. Emerhirhi ${ }^{2}$ \\ ${ }^{I}$ Department of Agricultural Extension, Federal University of Technology, Owerri, Imo State, Nigeria \\ ${ }^{2}$ Department of Agricultural Science Education, Federal College of Education, Omoku, Rivers State, Nigeria \\ *Corresponding author
}

\begin{abstract}
This study was carried out to analyze indigenous knowledge practices employed by farmers for climate change adaptation and mitigation by farmers in Southeast Nigeria. A total of 360 farmers were randomly selected from 3 states of Southeast, Nigeria. Questionnaires and oral interview were used to elicit information from the respondents. Mean and Standard deviation were used to analyze data collected. Results showed that the famers were fully aware of climate change variability as indicated by a high mean score of the various prediction signs such as erratic rainfall pattern $(M=3.25)$, heavy flooding $(M=2.65)$, long rainfall $(M=3.36)$ among others. To adapt and mitigate climate change, the farmers used the following indigenous practices- crop diversification $(M=3.46)$, crop rotation $(M=2.61)$, multiple cropping $(M=3.03)$, mulching ( $M$ $=2.44)$ soil fertilization $(M=2.98)$, agro forestry $(M=2.79)$, use of planting pits $(M=2.74)$, use of calabashes to store water $(M=3.41)$, use of ashes for pest control $(M=3.84)$, use of cannabis to control new castle diseases $(M=2.40)$ etc. The above practices are safe and have proved successful for centuries and we recommend that they should be integrated into the modern practices of agriculture.
\end{abstract}

\section{Introduction}

Agriculture places heavy burdens on the environment in the process of providing populations with food and fibre, while climate is the primary determinant of agricultural productivity. Given the fundamental role of agriculture in human welfare, concern has been expressed by federal agencies and others regarding the potential effect of climate change on agricultural productivity. Interest in this issue has motivated a substantial body of research on indigenous knowledge (IK) of climate change and agriculture in recent decades (Nelson et al., 2009; Lobell et al., 2008; Darwin, 2004; Fischer et al., 2002).

\section{Article Info}

Accepted: 25 August 2018

Available Online: 20 September 2018

\section{Keywords}

Indigenous knowledge, agriculture, crops, animals, water, management 
The terms indigenous, traditional and/or local knowledge make reference to knowledge and know-how that is accumulated over generations and guides human societies in their innumerable interactions with their surrounding environment. Mafongoya and Ajayi (2017) defines such traditional, ecological knowledge as "a cumulative body of knowledge, practice and belief, evolving by adaptation processes and handed down through generations by cultural transmission, about the relationship of living beings (including humans) with their environment." An abundance of labels for IK coexist in the literature. Common names include, but are not limited to: indigenous knowledge, traditional knowledge, traditional ecological knowledge, local knowledge, farmers' knowledge, ethno-science, folk knowledge and indigenous science or ethno-science.

Valuable local knowledge of relevance to climate change assessment and adaptation is held by rural societies (Mafongoya and Ajayi, 2017). These knowledge systems are transmitted and renewed by each succeeding generation, ensuring the wellbeing of people by providing food security, environmental conservation, and early warning systems for disaster risk management. IK is considered as social capital for the poor and is relied upon for food production and to ensure survival. However, IK is gradually disappearing due to the invasion of development concepts, which promise development goals or solutions, but are not sustainable. The tragedy of the disappearance of this knowledge is obvious to the local indigenous communities, and the implications for others can be detrimental when local skills, teachings and expertise are lost.

Most studies on indigenous perceptions of climate change have been carried out in the developed countries of the world, which dominate the uppermost northern region of the earth and where the relationship between scientists and indigenous people is high (Jan and Anja, 2007).

Despite the fact that efforts have been made towards the fight against climate change from a scientific perspective, research and policies directed towards the incorporation of IK within climate change strategies are desperately needed. The study of local perception is useful in understanding the true implication of a changing climate (Adesiji et al., 2013).

Most third world countries, especially in Africa, have been making serious and frantic efforts to untangle development problems. Persisting problems include economic stagnation, declining agricultural productivity, natural resource degradation, insufficient infrastructure and a host of other socio-economic issues. However, awareness, understanding and use of local knowledge systems is one strategy that can help facilitate efforts to deal with these problems (Adedotun and Tunji, 1995).

\section{Objective of the Study}

The overall objective of this study was assessing the agricultural Indigenous Knowledge practices for Climate Change adaptation and mitigation by farmers in Southeast Nigeria.

\section{Specific objectives were}

To examine farmers perceived awareness of climate change variability in the study area;

To investigate the indigenous knowledge in crop management, land management, water management and pests/diseases control used by the respondents in responding to climate change.

\section{Materials and Methods}

The study area was South-east Nigeria, situated east of River Niger and covering an area of 29,908 square kilometers, with a population of about $16^{1 e} 381,729$. It comprises five States namely: Imo, Enugu, Anambra, Ebonyi and Abia. The States in the zone share essentially similar characteristics (NPC, 2006). The zone covers the bulk of the Igbo-speaking ethnic territory, the remainder of which extends westwards into Delta State and southwards into Rivers State. By territorial size, the South East zone is by far the smallest in Nigeria, accounting for a mere $3.2 \%$ of the national space. However, the 2006 census data credited it with $11.7 \%$ of the population, giving it a population density nearly four times the national average. High population pressure is indeed one of the basic facts of life in the zone. Generally, the State is rural with majority of the population engaging in subsistence farming as a means of livelihood. Major crops grown are yam, cassava, maize, cocoyam, melon, plantain, banana, garden egg, and vegetable, livestock (poultry, sheep, goat, and rabbit).

This study employed multi-stage random sampling technique. First stage was randomly selecting three States out of the five States that make up south-east zone of Nigeria. This included: Imo, Abia and Ebonyi States. 
The second stage was randomly selecting two Agricultural zones from each of the selected States. This gave a total of six Agricultural zones. The third stage of the sampling was the random selection of two Local Government Areas from each of the zones giving a total of twelve Local Government Areas. The fourth stage was the random selection of three communities from each Local Government Area, giving a total of thirty-six communities. The fifth stage was the random selection of one village from each community selected. The sixth stage was the random selection of ten household heads from each of the selected villages which gave a sample size of 360 household heads for the study. Data collections were both primary and secondary. The primary data were collected with the use of a structured questionnaire, complimented with Focus Group Discussions (FGD). The result of the FGD provided more insight to the study and validated the responses from the interview. The data generated were descriptively analyzed. Climate change awareness (objective 1) was measured on a 4-point Likert type rating scale of strongly agree, agree, disagree and strongly disagree assigned weight of $4,3,2,1$. The values were added and divided by 4 to get the discriminating mean value of 2.50 . Any mean value equal to or above 2.5 was regarded as being aware of climate change. Mean was also computed on a 4-point Likert type rating scale of strongly agree, agree, disagree and strongly disagree assigned weight of 4,3,2,1 to indigenous crop management practices, land management practices, water management practices and pest/diseases control measures (objective 2). The values were added and divided by 4 to get the discriminating mean value of 2.50. Any mean value equal to or above 2.50 was regarded as indigenous practices in the areas mentioned.

\section{Results and Discussion}

\section{Farmers awareness of climate change in the study area}

Table 1 revealed that the selected farmers were fully aware of climate change menace based on the signs seen so far by them. With a discriminating mean index of 2.50 , the following sign were seen by the respondents erratic rainfall pattern with a mean response of 3.25, long period of dry season $(\mathrm{M}=2.94)$, heavy and long period of rainfall $(\mathrm{M}=3.36$, $)$ high temperature $(\mathrm{M}=2.74)$, unusual heavy winds $(\mathrm{M}=3.39)$, occurrence of floods $(\mathrm{M}=2.65)$, loss of forest resources $(\mathrm{M}=3.00)$, occurrence of soil erosion ( $\mathrm{M}=2.84)$, drying up of streams $\quad(\mathrm{M}=2.67)$ and overflowing of streams/river( $\mathrm{M}=2.54)$. These were obvious signs of climate change which convinced them that climate change is real and its happening. Awareness of signs of climate change helps the farmers know the indigenous farm practices to employ to adapt and mitigate climate change variability.

La Trober (2002) agrees with the above findings when he said observed changes include lengthening of mid to high latitude growing seasons, populations, and altitudinal shifts of plant and animal ranges, declines of some plant and animal populations, and earlier flowering of trees, emergence of insects, and egg-laying in birds. Moreover sea levels have shown signs of rising, and in some regions, including within Africa and Asia, floods and droughts have been observed to increase in recent years. Many rural farmers in developing countries, are already seeing the effects of climate change daily in the reduced availability of water for their agriculture. ( $\mathrm{La}$ Trober, 2002).

\section{Indigenous Crop Management Practices of Respondents}

Table 2 showed the indigenous crop management practices used by the farmers for adaptation and mitigation to climate change. These practices are discussed below: crop diversification $(M=3.46)$, crop rotation ( $\mathrm{M}=2.61)$, and mixed farming $(\mathrm{M}=2.58)$. It is perceived as one of the most ecologically feasible, cost effective, and rational ways of reducing uncertainties in agriculture especially among smallholder farmers (Joshi 2005). Also, crop diversification increases resilience and brings higher spatial and temporal biodiversity on the farm (Joshi 2005). According to Lin (2011), crop diversification improves soil fertility, controls for pests and diseases, and brings about yield stability, nutrition diversity, and health. It can also serve as a superior substitute for the use of chemicals to maintain soil fertility and control pests. Truscott et al., (2009) considers crop diversification an environmentally sound alternative to the control of parasites and in the maintenance of soil fertility in agriculture. Diversified cropping systems, in general, tend to be more agronomically stable and resilient. This resilience is mainly because they are usually associated with reduced weed and insect pressures, reduced need for nitrogen fertilizers (especially if the crop mix include leguminous crops), reduced erosion (because of cover crops inclusion), increased soil fertility and increased yield per unit area (Lin 2011). Moreover, diversified cropping systems can also provide habitats for beneficial insects, 
and this can help reduce the number of pests by rendering host crops less apparent for colonization by parasites.

\section{Changing time of planting $(M=2.87)$}

Farmers employed various indigenous practices most of which were cross cutting among the crops grown. Early planting is one of the pillars for both indigenous and improved farming methods practiced. This is especially important in this agro-ecological zone where agriculture is rain-fed. Farmers take advantage of the early rains which also reduce the incidences of pest and disease leading to high yields. For grain crops like beans, farmers ensure that beans are planted as the second crop in the rotation system. Broadcasting the seed before ploughing is still a popular method used when planting. Early plating is also preferred to allow crops receive enough rainfall and reduce pests and diseases incidences.

\section{Seed Selection by colour $(M=2.93)$}

The respondents reported that, subsequent to harvesting, the crops are threshed and carefully stored for use. The seeds are carefully selected for planting in the next season. Good seeds are selected by colour. Only bright coloured and large-sized seeds are selected for planting. Sometimes selection of the best seeds is done by soaking the seeds in water. Only the sinking seeds are selected and the floating seeds are not selected. Olatokun and Ayanbode [2010] observe that Nigerian women cull the seeds and preserve them for the next planting season. In Ethiopia, the farmers select healthy crops in terms of maturity period, height, colour, and size. The panicles or the spikes of the selected varieties are separately harvested, dried, carefully threshed, and the grains are saved for replanting (Belemie, and Singh, 2010]. Farmers also practice selection of clean planting materials as in the case of formal research to control pests and diseases. For the case of cassava, they ensure that the cuttings are not damaged prior to planting and that nodes face downwards to encourage effective sprouting and root growth. Farmers relied on crop rotation to rejuvenate the soil.

\section{Multiple Cropping $(\mathrm{M}=\mathbf{3 . 0 3})$}

Sowing of seeds is done haphazardly by hand. All seed varieties are sown simultaneously in the same field. This practice maximises the growth of all crops at the same time in the same field. Inter-planting allows cropping systems to reuse their own stored nutrients [Miguel and
Parviz, 2008]. With this system productivity per unit area is higher than in mono-cropping systems with the same level of management. The farmers incorporate a variety of crops with different growth habits in the same field or home-gardens to maximise the chances for production of multiple crops [Rankoana, 2016]

\section{Storage of Seeds and Crops $(M=2.90)$}

After harvesting and threshing, the crops are stored and prevented from attack by weevils. The crops remain fresh until they are all consumed. The most common preservation practice mentioned by the participants is by hanging the maize, sorghum and millet cobs from the hut roof. Sometimes the seeds are mixed with the ash of Aloe ferox and stored into clay-pots and baskets. The seeds could last for more than five seasons. Chili pepper (Capsicum annum.) is used to preserve harvested cowpea in storage (Altieri, 1991).

\section{Use of indigenous grain crops $(M=2.85)$}

Many farmers prefer the use of indigenous grains such as millets and sorghums that are more drought-resistant than maize and also produce high yields with very little rain. Farmers also prefer specific crop varieties for drought seasons, such as an indigenous finger millet variety as it ripens fast, and an early maturing cowpea (Vigna unguiculata) variety. Generally, in areas with little moisture, farmers prefer drought-tolerant crops (like Cajanus cajan, sweet potato, cassava, millet, and sorghum), and management techniques emphasize soil cover (such as mulching) to reduce moisture evaporation and soil runoff. These varieties that exhibit high genetic variability have a huge untapped potential to be grown in many marginal environments of Africa and elsewhere threatened by climate change. These examples are of great significance because they help the resource-poor farmers living in marginal environments, providing the basis for adaptive natural resource management strategies that provides the opportunity for diversification of cropping systems which lead to greater stability and ecological resiliency under climatic extremes.

\section{Maintenance of Crops /hand weeding of crops ( $M=$ 2.69)}

It was reported that subsequent to planting, when the crops are about four weeks old, weeding commences. Weeds are removed by hand or hand-hoe to avoid them competing for moisture with the crops, thus disturbing 
the growth of crops. In Tanzania, when the farmers regard weed competition as negative for crop growth, they perform superficial hoeing, and leave the weeds on the soil surface as protective mulch, to recycle nutrients, and to allow nitrogen assimilation through the bacteria decomposing the plants (Adedipe et al., 2004). Olatokun and Ayanbode (2010) observed that tobacco (Nicotiana tabacum) plants are used to prevent insect build-up on the cocoa plantation. In Indonesia, the farmers burn the common lake-growing plant called Jariamun (Potamogeton. malaianus miq) in the middle of the ricefield to drive pests from the farm (Wahyudy et al., 2012).

\section{Cultural pest control $(\mathrm{M}=\mathbf{2 . 8 3})$}

Developing technologies to help farmers control pests remain important. Climate change could have positive, negative or no impact on each pest. There is need for better models to assess their global impact as most pest population prediction models have different spatial and temporal scales than global climate models (Woodley, 1991). Pests are usually controlled by cultural practices, natural enemies, host plant resistance, biopesticides and synthetic pesticides. But many of these control tactics are highly sensitive to the environment and climate change may render them less effective.

It may alter the interactions between pests and their host plants, directly affecting resistance to pest control. For example, there are indications that stem rot (Sclerotium rolfsii) resistance in groundnut is temperature dependent, while in Kenya resistance to sorghum midge (Stenodiplosis sorghicola) breaks down under high humidity and moderate temperatures. The traditional techniques used for pest control include use of hoe for weeding, intercropping and rotation patterns and pest resistant seed varieties. At germination stages, indigenous techniques such as hoe-weeding are applied while at later stages is complemented by the use of pest control chemicals as the crop grows. The implications of integrated pest management techniques are that the costs and side-effects of pest chemicals can be minimized. The uses of integrated techniques for pest management help to overcome the limitations which results from using indigenous and scientific techniques separately.

\section{Land management Practices for climate change adaptation and Mitigation}

The farmers adapt to climate change by employing a number of land management measures/practices. These practices are discussed below:

\section{Mulching with a mean score of 2.94}

Previously harvested residue in the form of maize stalks, dried bean and nut plants are a good soil stabiliser. The participants reported that after harvest, the residue is tilled with the soil to improve moisture retention and fertility of the soil. This indigenous practice, according to Buthelezi et al., (2010) replenishes depleted soil nutrients.

Again, farmers heap soil and trash around the plant while weeding and make bands. Water run off and/or soil erosion is reduced using soil bands. Farmers also add crop residues like kitchen waste/refuse and manure from goats, chicken, and cattle to their fields and fallow plots to enhance nutrient status.

Farmers mostly use elephant grass and maize stalks to conserve soil moisture and add manure after decomposition when mulching. Mulching was practiced in at least 4 out of 10 households in every village. Many farmers had stopped the bush burning practice and were making and applying compost manure.

\section{Land Fallowing $(\mathrm{M}=\mathbf{2 . 6 5})$}

In many instances exhausted fields are left fallow for two to five years. The participants agreed that this practice helps the soil regain fertility. During fallowing, cattle, sheep and goats are driven in the fields to browse course grass and that their droppings should add to soil fertility. Fallowing enables farmers capture the essence of natural processes of soil regeneration typical of ecological succession (Buckles et al., 1998). The use of "green manures", which is a recent discovery, intensifies the old fallowing technique in areas where long fallow periods are not possible anymore. It is widely recognized that forests play an important role in the global carbon cycle by sequestering and storing C (Karjalainen et al., 1994; Stainback and Alavalapati 2002). Local farmers are known to have practiced the fallow system of cultivation, which encouraged the development of forests.

It may be argued that with the growth in population, lengths of fallow have been reduced to the extent that the practice no longer exists in certain areas. However, one must not forget that the importance of forests have been recognized by traditional institutions to the extent that communal forest reserves were very common in traditional societies. Besides the fact that these well managed forests provided food and timber resources to the community, they also served as $\mathrm{C}$ sinks. 
Table.1 Farmers Awareness of Climate Change

\begin{tabular}{llc}
\hline Climatic signs & Mean & SD \\
\hline Erratic rainfall pattern & 3.25 & 0.48 \\
Long period of dry season & 2.94 & 0.87 \\
Heavy and long period of rainfall & 3.36 & 1.64 \\
High temperature & 2.74 & 1.55 \\
Unusual heavy winds & 3.39 & 0.83 \\
Occurrence of floods & 2.65 & 0.54 \\
Loss of forest resources & 3.00 & 0.77 \\
Soil erosion occurrences & 2.84 & 0.88 \\
Drying up of streams/rivers & 2.67 & 0.59 \\
Overflowing of streams/rivers & 2.54 & 0.66 \\
\hline
\end{tabular}

Table.2 Indigenous Crop Management Practices

\begin{tabular}{lll}
\hline Crop Management Practices & Mean & SD \\
\hline Use of indigenous grains & 2.85 & 1.09 \\
Crop diversification & 3.46 & 0.93 \\
Crop rotation & 2.61 & 0.96 \\
Mixed farming & 2.58 & 1.01 \\
Cultural pest control & 2.83 & 1.88 \\
Changing time of planting & 2.87 & 1.18 \\
Seed selection by colour & 2.93 & 1.22 \\
Multiple cropping & 3.03 & 1.17 \\
Hand weeding of crops & 2.69 & 1.10 \\
Storage of seeds & 2.91 & 1.13 \\
\hline
\end{tabular}


Table.3 Indigenous Land Management Practices

\begin{tabular}{lll} 
Indigenous Land Management Practices & Mean & SD \\
\hline Mulching & 2.94 & 1.19 \\
Land Fallowing & 2.65 & 1.20 \\
Use of mounds/ridges & 2.81 & 1.06 \\
Zero-tillage & 2.56 & 1.40 \\
Agro-forestry/tree planting & 2.79 & 0.96 \\
Knowledge of soil types & 2.66 & 1.06 \\
Establishment of sacred bush & 3.05 & 0.98 \\
Soil fertilization & 2.98 & 1.13 \\
Farmstead construction & 3.01 & 0.87 \\
\hline
\end{tabular}

Table.4 Indigenous Water Management Practices

\begin{tabular}{lll}
\hline Water Management Practices & Mean & Std \\
\hline Use/preparation of planting pit & 2.79 & 1.23 \\
Underground earthen jars/pots/tanks & 2.65 & 0.97 \\
Construction of infiltration pits & 2.84 & 1.04 \\
Construction of wells \& basin for water storage & 2.74 & 0.84 \\
Construction of soil/stone bunds & 3.06 & 0.71 \\
Use of large calabashes to store water & 3.41 & 0.64 \\
Traditional taboos & 2.94 & 0.54 \\
\hline
\end{tabular}

Table.5 Indigenous Pest/Diseases control/Health care Management Practices

Indigenous practices

Use of bitter leaf solution for de-worming

Making pepper/salt solution for treating cough

Use of banana /plantain peels with salt for delivery

Use of ashes for pest control

Use of neem solution for termite control

Use of urine for weevil/control of soil borne diseases

Use of vegetable to de-worm animal

Use of Canabis for control of new castle diseases

Removal of eggs by hand to increase number
Mean

2.53

2.88

2.64

3.20

2.68

0.89

2.24

0.74

2.06

0.71

2.40

0.73

2.12

0.54 
Zero-tillage $(\mathrm{M}=\mathbf{2 . 5 7})$

Local farmers in the area have been known to conserve $\mathrm{C}$ in soils through the use of zero tilling practices in cultivation, mulching and other soil management techniques (Schafer, 1989; Osunade, 1994). Natural mulches moderate soil temperatures and extremes, suppress diseases and harmful pests, and conserve soil moisture. Before the advent of chemical fertilizers, local farmers largely depended on organic farming, which also is capable of reducing GHG emissions.

\section{Agro-forestry/ tree planting $(\mathrm{M}=2.79)$, and establishment of sacred bush $(M=3.05)$}

Agroforestry is another practice that has been very effective in carbon sequestration. Agroforestry is a rational land-use planning system that tries to find some balance in the raising of food crops and forests (Adesina et al., 1999; Floyd, 1969). A practice similar to this has been described in a part of south western part of Nigeria to raise shade tolerant crops such as Dioscorea spp and cocoyam in essentially a permanent forest setting (Adesina, 1988), In addition to the fact that agro-forestry techniques can be perfected to cope with the new conditions that are anticipated under a drier condition and a higher population density, they lead to an increase in the amount of organic matter in the soil thereby improving agricultural productivity and reducing the pressure exerted on forests.

Traditional knowledge of plants is very useful in agroforestry projects. Scientists have tended to limit plants' trials for forestry and agroforestry to known species that have performed well in other parts of the world. In the drier parts of the Sahel, the significance of the baobab (Adansonia digirate) and acacia (Acacia) trees is just being realized by researchers as a valuable tree especially during the hot and dry parts of the year. Local people certainly know other trees that perform well under different ecological conditions. The integration of such candidates into the pool of suitable agro-forestry trees will provide opportunities for the farmers to make choices.

Local knowledge is vital for preserving biodiversity, which is considered a very successful mitigation strategy. Through the World Bank, gene banks have been established to preserve genetic information of local varieties or indigenous species. Genetic traits of these species and the knowledge of cultivators may prove instrumental in future breeding programs to introduce resistance against pests or diseases or endurance for harsh climatic conditions (Warren, 1991). Hence, these gene banks should cooperate with farmers and communities who still cultivate local varieties to preserve such essential knowledge and skills in situ.

\section{Knowledge of soil types by colour $(M=2.66)$}

Knowledge of soil varieties by colour and texture, and the types of crops that do well on particular soil types, was evident among the participants. According to the respondents, black clayey soil is rich in nutrients and good for cultivation of maize, pumpkin, and gourds. Sandy soil is good for beans, melons, and sweet-reed. Another type of soil is a mixture of sandy and clayey soil which is good for all crops. Farmers expressed reasonable knowledge on soil fertility indicators. This is mainly determined by soil characteristics, types of weeds growing in an area and crop characteristics such as yields, vigor and the general appearance of the plants. Soil types, degrees of soil fertility, and land use categories were also desegregated by farmers. Color, texture and even taste usually distinguish soil types while some classified their soils based on vegetative cover. These findings are supported by observations that African subsistence farmers' knowledge of soil is based on colour and texture of the topsoil, that dark soil indicates higher fertility while lighter soil signifies lower fertility (Buthelezi et al., 2010).

\section{Soil Fertilization}

With mean response of 2.98. The respondents agreed that they apply poultry manure to make the soil regain fertility, retain moisture, and avoid pests. This type of soil fertilization mainly improves soil moisture conservation [Mapaure, 2011]. In Tanzania, subsistence farmers understand that if weeds are left to grow, they cover the soil, prevent it from heating up or drying out excessively, induce a positive competition, which simulates crop growth and reduces erosion during rainfall [Olatokun,and Ayanbode, 2010]. With the realization of declining soil quality and productivity, several indigenous management practices have evolved over the years to conserve the soil. Some of these practices include: bush fallowing, organic manuring, intercropping, crop rotation, agro forestry and conservation tillage. Bush fallowing involves the use of natural fallows to regenerate or restore soil fertility by the farmers. In some areas, leguminous plants are used for quick restoration of soil fertility. Example, Centrosema spp is used to fix nitrogen into the soil in 
order to improve its fertility [Tarawali and Ogunbile, 1995]. The application of compost, animal waste and domestic wastes to soil is referred to as organic manuring. This helps to maintain soil microbial activities and promote absorption of nutrients by plants. Farmers use this practice to improve soil fertility. Intercropping is a practice of cultivating more than one type of crop on a piece of land at the same time. This practice removes the risk of total crop failure as well as providing good soil cover that minimizes soil erosion. Farmers also use conservation tillage (minimum and zero tillage) to respond to rapid soil deterioration and degradation caused by conventional tillage under harsh climatic environment and fragile soils. This system has the advantage of conserving the soil because of minimal disturbance [Idoga et al., 2004]. It therefore becomes pertinent for integrated approach to be developed in order to guarantee adequate food production and at the same time conserve the soil in the face of challenges of climate change

\section{Farmstead construction $(\mathrm{M}=\mathbf{3 . 0 1})$}

Indigenous peoples around the world may suffer most from climate change due to acombination of their high dependence on ecosystems, occupation of marginal lands, social pressure and lack of political representation. 'Because of their long dependence on nature they have developed strategies to cope with climate change and extreme natural events which still have as much relevance today as they did hundreds of years ago. People here built houses of bamboo on stilts, so that floodwater passes underneath the floor of the house without damaging it. During earthquake, the bamboo houses away back and forth but no damage is done. Many dry land areas face severe an degradation, in which marginal areas are turned into wastelands and natural ecosystem are altered through destruction of surface vegetation. (Mukhopadhyay, 2009).

\section{Indigenous Water Management Practices}

The following traditional water management practices were used by the respondents based on table 4 - planting pits $(\mathrm{M}=2.79)$, underground earthen jars $(\mathrm{M}=2.65)$, construction of infiltration pits $(\mathrm{M}=2.84)$, construction of wells/basins for water storage $(M=2.74)$, construction of soil/stone bunds $(\mathrm{M}=3.06)$, use large calabashes ( $\mathrm{M}$ $=3.41)$ and traditional taboos for water protection $(\mathrm{M}=$ 2.94). Again, a wide variety of traditional and innovative rainwater harvesting systems is found in Africa's Sahel zone. In semi-arid areas of Niger, small-scale farmers use planting pits to harvest rainwater and rehabilitate degraded land for cultivation of millet and sorghum. The technology improves infiltration and increases nutrient availability on sandy and loamy soils, leading to significant increases in yields, improved soil cover and reduced downstream flooding [FAO, 2008]. Farmers harvest water from rooftops and divert water from natural springs into tanks. This ensures that they have a substantial amount of water stored up. In case of a drought, the stored water will be able to sustain them for about five months depending on the volume of the tank. The water is also used for supplementary irrigation of vegetables and crops. Some farmers dig infiltration pits along contours. Water collects in the pits during the rainy period. When the weather becomes dry, as in the case of a short period of rains, the water infiltrates underground and is used by the plants. Crops can grow up to maturity by using this conserved moisture. Farmers' experience shows that even if there are only five days with rain in the whole rainy season, the crops will reach maturity using conserved and harvested water in the pits [Altieri and Nicholls, 2004]. Farmers practicing dry season agriculture harvest rain water and conserve it in basins or wells. In the dry season, the water conserved in the wells and basins is used for irrigation. Combinations of indigenous and scientific techniques have the potentialities of contributing to productivity and also sustaining the farming system.

\section{Indigenous Pest /Disease control/healthcare Management Practices in Agriculture}

Table 5 showed the pest control and healthcare management practice in agriculture for crop and animals. Farmers use local knowledge to treat their animals and maintain the growth of crops in the field. The following pest control/healthcare management practices are used use of bitter leaf solution for de-worming ( $\mathrm{M}=2.53$ ), making pepper/salt solution for treating cough in chicks $(\mathrm{M}=2.88)$, use of banana peels with salt for animal delivery $(\mathrm{M}=2.64)$, use of ashes for pest control $(\mathrm{M}=$ $2.68)$, removal of eggs by hand to increase the number of eggs laid $(\mathrm{M}=2.12)$ and the use of cannabis to control new castle disease of poultry $(\mathrm{M}=2.40)$. Chicken are fed on a mixture of millet and paraffin to prevent coccidiosis. This however is believed to make the hens take longer to lay eggs. Chicken infected with coccidiosis are injected with or given mixture of ash, ground pepper and water to drink. Indian hemp (cannabis) is mashed and added to water and used for treating coccidiosis. To destroy pests, farmers apply paraffin and vaseline on affected area especially around 
the chicken eyes. An old tyre is burnt in chicken coop to destroy mites. Farmers also cut and place a moist tree branch in the chicken coop to attract and trap mites which is removed and thrown far from the homestead when it is laden with the pests. In tobacco growing areas, farmers spread fire cured tobacco leaves on the chicken coop floor to kill mites. Pawpaw seeds also are given to chicken as de-wormers. Farmers use their hands to aid goats experiencing difficulties while delivering. In case the placenta fail to disengage, farmers give the goats cowpea leaves. Others prefer to hit the bottom of the goats with brooms ease the release of the placenta. Another remedy is giving goats a mixture of water and salt to aid the disengagement of the placenta after the goat delivers. When a pregnant goat fails to deliver, it is tied near a fireplace to presumably burn fats believed to block delivery.

The study results show that indigenous knowledge is still valuable in the community. The knowledge is embedded in the community's cosmology. Knowledge of plant phenology, and the appearance and shape of the moon and stars is used to plan the planting of crops. The materials used to fertilise the soil, mulch, manage crops, and the seeds are procured at the household level. Soil fertilizers, mulching ingredients and crop management materials are locally developed, always available, affordable, and culture-specific. The study concludes that subsistence farming is sustained by indigenous farming practices and rainfall prediction. The practices involve the improvement of soil structure, maintenance of crops, and the selection and storage of seeds for replanting.

\section{References}

Adedipe, N.O.; Okuneye, P.A.; Ayinde, I.A. (2004) The Relevance of Local and Indigenous Knowledge for Nigerian Agriculture. In Presented at the International Conference on Bridging Scales and Epistemologies: Linking Local Knowledge with Global Science in Multi-Scale Assessments, Alexandria, Egypt, 16-19 March.

Adedotun, O.P. and Tunji, T. 1995. Indigenous Knowledge Systems and Practices: Case Studies from Nigeria. Nigerian Institute of Social Economic Research, Ibadan, Nigeria.

Adesiji, G.B., Matanmi, B.M., Onikoyi, M.P. and Saka, M.A. 2012. 'Farmers perception of climate change in Kwara state, Nigeria'. World Rural Observation 4 (2): 46-54.

Adesina, F.A. (1988) Developing Stable Agroforestry Systems in the Tropics: An Example of Local Agro- forestry Techniques from South Western Nigeria. Discussion Papers in Geography 37. Department of Geography. University of Salford, United Kingdom.

Adesina, F.A. Siyambola, W.O. Oketola, F.O., Pelemo, D.A., Ojo, L.O. and Adegbuge, A.O. (1999) Potentials of Agro-forestry for Climate Change Mitigation in Nigeria some Preliminary Estimates. Global Ecology Biogeography 8:163-173.

Altieri MA, Nicholls, CI. Biodiversity and Pest Management Agroecosystems. $2^{\text {nd }}$ edition. Haworth Press, New York; 2004.

Altieri, M. (1991) Traditional farming in Latin America. Ecologist, 21, 93-96.

Belemie, K; Singh, R.K. Conservation of socio-culturally important local crop biodiversity in the Oromia Region of Ethiopia: A case study. Environ. Manag. 2012, 50, 352-364.

Buckles, D.; Triomphe, B.; Sain, G. (1998) Cover Crops in Hillside Agriculture: Farmer Innovation with mисипа; International Development Research Center: Ottawa, ON, Canada.

Buthelezi, N.; Hughes, J.; Modi, A. (2010) The Use of Scientific and Indigenous Knowledge in Agricultural Land Evaluation and Soil Fertility of Two Villages in KwaZulu-Natal, South Africa. In Proceedings of the World Congress of Soil Science, Soil Solutions fora Changing World, Brisbane, Australia, 1-6 August 2010.

Darwin, R. 2004. 'Effects of greenhouse gas emissions on world agriculture, food consumption and economic welfare'. Journal of Climate Change 66: 191-238.

Fischer, G., Shah, M. and Velthuizen H. 2002. Climate Change and Agricultural Vulnerability. International Institute for Applied Systems Analysis, Vienna, Austria.

Floyd, B., (1969). Eastern Nigeria: A Geographical Review Fredrick. A-Praeger, New York.

Food and Agriculture Organization. Organic agriculture and climate change. Retrieved, arcj 8. 2010; $2008 \mathrm{~b}$. Available: http://www.fao.org/DOCREP/oo5

Idoga, S, Obasi MO, Usman HI. (2004) Review of indigenous methods of soil conservation. In: Obinne CPO, Kalu BA, Umeh JC, editors. Indigenous Knowledge and Sustainable Agricultural Development in Nigeria. Proceedings of the National Conference on Indigenous Knowledge and Development. 2004:197-204

Jan, S. and Anja, B. 2007. Indigenous People and Climate Change. University of Oxford and Botanical Garden, Oxford, UK. 
Joshi, P. (2005) Crop diversification in India: nature, pattern and drivers. In: New Delhi India: Asian Development Bank

Karjalainen, T., Kellomski, S., and Pussinen, A., (1994) Role of Wood Based Products in Absorbing Atmosphere Carbon. Silva Fennica 25 (2): 67-80.

La Trober, S. (2002) Climate change and Poverty. A Discussion Paper of TEARFUND. Christian Action with the World's Poor. Tear fund Office, London

Lin, B.B. (2011). Resilience in agriculture through crop diversification: adaptive management for environmental change. Bioscience. 2011; 61:183193. doi: 10.1525/bio.2011.61.3.4.

Lobell, D.B., Burke, M.B., Tebaldi, C., Mastrandrea, M.D., Falcon, W.P and Naylor, R.L. 2008. Prioritizing climate change adaptation needs for food security in 2030'. Journal of Science 319 (5863): 607-610.

Mafongoya, P.L. and Ajayi, O.C. (editors), 2017, Indigenous Knowledge Systems and Climate Change Management in Africa, CTA, Wageningen, The Netherlands, 316pp

Mapaure, I. Mhango, D. Mulenga, K. (2011) Mitigation and Adaptation Strategies to Climate Change; John Meinert Printing: Windhoek, Namibia,

Mukhopadhyay, D. (2009) Cultural Values, Indigenous Knowledge for Climate Change Adaptation in Developing Countries. Earth and Environmental Science (6)570006.

Nelson, G.C., Rosegrant, J., Koo, R., Robertson, T., Sulser, T., Zhu, C., Ringler, S., Msangi, A., Palazzo, M., Batka, M., Magalhaes, R., Valmonte-Santos, Wing, M.E. and Lee, D. 2009. Climate Change: Impact of Agriculture and Cost of Adaptation. International Food Policy Research Institute, Washington DC, USA.

Olatokun, W.M.; Ayanbode, O.F. (2010) Use of indigenous knowledge by rural women in the development of Ogun State. Indilinga, 20, 47-63.

Osunade, M.A. (1994). Indigenous Climate Knowledge and Agricultural Practices in South Western Nigeria. Malaysia Journal of Tropical Geography 1:21-28.

Rankoana, S.A. (2016) Perceptions of climate change and the potential for adaptation in a rural

\section{How to cite this article:}

Chikaire J. U., N. E. Okereke - Ejiogu and Emerhirhi E. 2018. Sustainable Indigenous Knowledge Systems in Agriculture for Climate Change Adaptation and Mitigation in Southeast Nigeria. Int.J.Curr.Res.Aca.Rev. 6(9), 97107. doi: https://doi.org/10.20546/ijcrar.2018.609.010 community in Limpopo Province, South Africa. Sustainability, 8, 672

Schafer, J. (1989). Utilizing Indigenous Agricultural Knowledge in the Planning of Agricultural Research Projects Designed to Aid Small-Scalefarmers. In Warren, D.M. Sukkerveer, L.J. and Titilola, S.O. (Eds) Indigenous Knowledge Systems: Implications for Agriculture and International Development. Studies in Technology and Social Change No 11, Technology and Social Change Programme, Lowa State University.

Simonelli, M.T. 2008. Climate Change and Indigenous Knowledge. Higher Educational Handbook Series. Keynote Publishers Limited, Ilesa, Nigeria.

Stainback, G.A., and Alaralapati, J. (2002). Economic Analysis of Slash Pine Forest Carbon Sequestration in the Southern United States. Journal for Economics 8:105-117.

Tarawali G, and Ogunbile, O.A. (1995) Legumes for sustainable food production in Semi-arid Savanna. ILEIA Newsletter for Low External Input and Sustainable Agriculture. Farmers facing change. 1995; 11(4):18-19.

Truscott, L, Aranda, D, P, S., A.L. (2009) A snapshot of crop diversification in organic cotton farms. In: Discussion paper. Soil Association

Wahyudy, D.; Anwar, K.; Angelika, A.; Nayu, N.W. Role of Indigenous Knowledge in Traditional Farming System on Natural Resources Management. 2012. Available online: https://www.uni-

kassel.de/fb11agrar/fileadmin/datas/fb11/Oekologis che_Lebensmittelqualit\%C3\%A4t_und_Ern\%C3\% A4hrungskultur/Bilder/David._W_Ploeger_A._Role _of_Indigenous_Knowledge_in_Traditional_Farmin g_System_on_Natural_Resources_Management.pdf (accessed on 22 September 2016).

Warren, D.M. (1991) Using Indigenous Knowledge in Agricultural Development World Bank Discussion Paper No 127. World Bank, Washington, D.C.

Woodley E. (1991) Indigenous ecological knowledge systems and development. Agric Human Values. 8:173-178 